\title{
MSMEs and Digital
}

\section{Fidelia Rahayu Kencanasari}

The number of MSMEs that are starting to grow very much in Indonesia, assisted by the sophistication of technology that is increasingly developing makes MSMEs very able to get the public market. There are many platforms that can be used by MSMEs to sell and for example, Shope, Tokopedia and many more. MSMEs on these platforms are more sought after by the public now because it is easier to find only through smartphones, there are many choices and the important thing is that the price you get is much more affordable than buying goods directly at the store, so people, especially Indonesians, are more likely to shop online.

The convenience that is obtained through online shopping is more felt by the people of Indonesia, making swords now starting to compete to collaborate with various existing platforms to keep getting customers and customers don't run to other stores. Coupled with the Covid-19 which is very rampant now, the platform has become the mainstay of the Indonesian people to buy goods.

The criteria for traders who enter MSMEs are traders who each year get an income of IDR 50 million to IDR 500 million. As many as 12 million small entrepreneurs owned by Indonesia make MSMEs have a contribution of 99\% to the Indonesian national economy. To help carry out economic recovery for small traders such as street vendors, street vendors, small kiosks, market traders, and food stalls, the government has prepared a budget of Rp. 8 trillion to be able to help business capital for MSMEs.

Digitalization has proven to be able to support the economic recovery program due to Covid-19, making the central, provincial, district and city governments including BUMN and BUMR carry out development and empowerment efforts for MSMEs in Indonesia. The 
government makes various schemes to be able to help and support MSMEs by providing soft credit assistance, MSME partnerships with large companies, plasma and plasma core models and the development of superior MSME products. halal MSME products to be able to strengthen exports and strengthen access to international markets and can also strengthen the position of exporters of halal products. The government also helps MSMEs to obtain Halal certification for export purposes and are able to penetrate the export market without being limited by tariff and non-tariff barriers.

\section{Referensi}

Tayibnapis, Ahmad Z.; Wuryaningsih, Lucia E.; and Gora, Radita. 2021. Medium. Small. And Medium Enterprises and Digital Platforms. South Asian Journal of Social Studies and Economics. 10(2): 10-19, 2021. 